\title{
Considerações sobre o Direito Humano à Saúde
}

\author{
CONSIDERATIONS ABOUT THE HEALTH HUMAN RIGHT
}

Péricles Asbahr ${ }^{(*)}$

\section{RESUMO}

O presente estudo trata do direito à saúde como um direito fundamental da pessoa humana, levando em consideração a história e a evolução dos direitos humanos. O direito à saúde foi positivado constitucionalmente, conformando-se à feição programática e progressiva que revestem as normas internacionais dos direitos humanos de segunda geração, de sorte que a efetivação desse direito depende da adoção e realização de politicas públicas especificas. O fim precipuo deste trabalho é demonstrar que a Constituição brasileira, ao consagrar a saúde como um bem juridico fundamental e direito de todos e indicar politicas, meios e recursos para a satisfação do direito à saúde, tornou-o justiciável, traçando a sua primeira condição de eficácia jurídica. Como nenhum direito é absoluto, são discutidos os limites de concretização do direito sanitário, quais sejam: a reserva juridica e fática do possivel, o principio da proporcionalidade e a reserva da consistência.

\section{Descritores}

Direito sanitário; direitos humanos sociais; tutela da saúde; eficácia e efetividade do direito sanitário; limites de concretização judicial do direito sanitário.

\section{ABSTRACT}

The present study deals with the health law as a social human right, taking into account the human rights history and evolution. The health law

(*) Engenheiro Quimico, Advogado em Sảo Paulo, Especialista em Engenharia Sanitária e Direito Sanitário pela FSPUSP, Especialista em Direito do Consumidor pela UniFMU e Mestrando em Direito Ambiental pela UNISANTOS. E-mail: ppasbahr@terra.com.br. Recebido: 22.3.04, Aprovado: 23.5.04. 
has been made constitutionally positive, complying with the programmatic and progressive aspect that points out the second generation of international human rights rules, in such a manner that this right effectiveness depends on the adoption and accomplishment of specific public policies. The objective of this study is to demonstrate that the Brazilian Constitution, when selects health as a fundamental legal item and everyone's right and indicates policies, ways and resources to the fulfillment of health law, has made it justiciable, delineating its first condition of legal efficacy. As no right is absolute, it is discussed the limits for the completion of sanitary law, as such: the legal and factual reserve of the feasible, the proportionality principle and the consistence reserve.

\section{Key words}

Sanitary law; social human rights; health's tutelage; sanitary law efficacy and effectiveness; sanitary law juridical completion limitation.

\section{INTRODUÇÃO}

O direito à vida consiste no primordial direito do ser humano, posto que dele derivam os demais direitos. Mais do que se manter vivo, o direito à vida significa a possibilidade de que a pessoa humana tenha condições de capacitar o pleno desenvolvimento das faculdades físicas, mentais e sociais que the são próprias.

Nesse contexto, o direito à saúde pode ser entendido como um conjunto de deveres do Estado para com todo cidadão, que visa não apenas afastar as enfermidades mas também garantir o desenvolvimento saudável da população(1).

A Constituição da República Federativa do Brasil promulgada em 5 de outubro de 1988 - CF/88 - consagrou pioneiramente o direito social à saúde como direito e dever fundamental da pessoa humana(2). Com efeito, a atual Carta Magna, além de reconhecer o direito à saúde como direito

(1) Saúde para a Organização Mundial da Saúde - OMS é o completo bem-estar físico, mental e social, e não apenas a ausência de doença, reconhecendo assim a essencialidade do equilibrio interno e do homem com o ambiente (Preâmbulo da Constituição da OMS, assinada em 26 de julho de 1946).

(2) Cf. Sueli Gandolfi Dallari, o direito sanitário diz respeito tanto ao direito à saúde, enquanto trata de reivindicação de um direito humano, quanto ao direito da saúde pública, "que é um conjunto de normas juridicas que têm por objeto a promoção, prevençáo e recuperação da saúde de todos os individuos que compõem o povo de determinado Estado, compreendendo, portanto, ambos os ramos tradicionais em que se convencionou dividir o direito: o público e 0 privado". Direito Sanitário. In: Curso de especialização em direito sanitário para membros do Ministério Público e da Magistratura Federal/Ministério da Saúde. Programa de Apoio ao Fortalecimento do Controle Social do SUS. Brasilia: Ministério da Saúde, 2002. p. 58. 
fundamental previsto genericamente no art. $6^{\circ}$, juntamente com outros direitos fundamentais sociais, definiu também os principios norteadores da politica pública da saúde (arts. 196 a 200).

Adverte-se, entretanto, que a saúde não é apenas um direito humano fundamental, mas também um dever, isso porque o próprio texto constitucional expressa claramente tal disposição no art. 196, ao prever que "a saúde é direito de todos e dever do Estado, garantido mediante politicas sociais e econômicas que visem à redução do risco de doença e de outros agravos e ao acesso universal e igualitário às ações e serviços para a sua promoção, proteção e recuperação"(3).

Cabe ao Poder Público regulamentar, fiscalizar e controlar as ações e serviços de saúde (art. 197), os quais integram uma rede regionalizada e hierarquizada e constituem um sistema único - SUS (art. 198), cujas atribuições estão previstas no art. 200, permitindo-se complementação da assistência à saúde à iniciativa privada (art. 199).

Além disso, há pactos internacionais ratificados e incorporados ao ordenamento juridico nacional que integram o direito social à saúde na ordem constitucional vigente, isso porque de acordo com o disposto no art. $5^{\circ}, \S 2^{\circ}$, da CF/88, os direitos e garantias fundamentais compreendem também os direitos humanos previstos nos tratados internacionais em que o Brasil seja parte ${ }^{(4)}$.

Sob a ótica constitucional, como salienta Sarlet( ${ }^{(5)}$, há dois aspectos fundamentais, formal e material, que caracterizam o direito à saúde, tal como outros direitos e garantias fundamentais. No aspecto formal, a saúde é um direito constitucional positivado que se desdobra em três ele-

(3) Essa norma rompeu com a divisão anterior entre os segurados da previdência social e os não-segurados. "Como direitos a todos, a saúde não requer nenhum requisito para a sua fruição, devendo ser universal e igualitário o acesso às ações e serviços de saúde, 'em todos os niveis de assistência' (art. $7^{\circ}, 1$, da LOS). Além disso, a assistência à saúde deve estar pautada pela igualdade, 'sem preconceitos ou privilégios de qualquer espécie' (art. $7^{\circ}$, IV, da LOS)" . Cf. MAUÉS, Antonio G. Moreira; SIMŐES, Sandro Alex. Direito público sanitário constitucional. In: Curso de especialização em direito sanitário para membros do Ministério Público e da Magistratura Federal/Ministério da Saúde. Programa de Apoio ao Fortalecimento do Controle Social do SUS. Brasilia: Ministério da Saúde, 2002. p. 483.

(4) Diz o art. 25 da Declaração Universal dos Direitos Humanos de 1948: "Toda pessoa humana tem direito a um padrão de vida capaz de assegurar a si e a sua familia saúde e bem-estar, inclusive a alimentação, vestuário, habitação, cuidados médicos e os serviços sociais indispensáveis, (...)". A Declaração Americana dos Direitos e Deveres do Homem de 1948, por sua vez, estabelece no art. 11 que a saúde da pessoa é protegida através de medidas sanitárias e sociais que incluem: alimentação, roupas, habitação e cuidados médicos correspondentes ao nivel permitido pelos recursos públicos e os da coletividade. Já o $\S 1^{2}$ do art. 12 do Pacto Internacional dos Direitos Económicos, Sociais e Culturais de 1966 reconhece o direito de toda pessoa desfrutar o mais elevado nivel de saúde física e mental.

(5) SARLET, Ingo Wolfgang. Algumas considerações em torno do conteúdo, eficácia e efetividade do direito à saúde na Constituição de 1988. Revista Diálogo Jurídico, Salvador, n. 10, p. 3, 2002. Disponivel em: <http://www. direitopublico.com.br>. Acesso em: 19.jul.2004. 
mentos: a) é uma norma superior hierárquica; b) sofre limites formais e materiais por se constituir em cláusula pétrea ${ }^{(6)}$; $\left.c\right)$ é norma diretamente aplicável, vinculando o Estado e os particulares, a teor do que dispõe o art. $5^{\circ}, \S 1^{\circ}$, da CF/88 ("As normas definidoras dos direitos e garantias têm aplicação imediata").

Sob o aspecto material, não há dúvida quanto à importância da saúde para a vida e a dignidade humana, razão pela qual a saúde é um relevante bem juridico tutelado pela ordem constitucional no titulo dedicado à ordem social.

A constitucionalização do direito fundamental à saúde acarreta outras conseqüências juridicas: a) abre caminho para que todos os cidadãos brasileiros possam usufruir saúde, uma vez que ela constitui direito público subjetivo garantido pelo SUS; b) afora o seu valor subjetivo, o direito sanitário ganha uma dimensão objetiva, passando a ser um bem jurídico protegido não só pelo Estado mas também pela sociedade; assim, ainda que não ocorra violação direta do direito subjetivo à saúde, é possivel invocar ação judicial por ação ou por omissão do Poder Público que afete esse bem juridico; c) cabe ao Poder Público proteger a saúde no âmbito das relações privadas, devendo o legislador estabelecer legislação adequada a essa proteção e os tribunais interpretar as normas do direito privado em consonância com a Constituição, declarando, por exemplo, a inconstitucionalidade de leis violadoras da saúde, ou, anulando cláusulas contratuais abusivas de planos de saúde(7).

Isso, contudo, não tem sido o bastante, pois o reconhecimento e a declaração constitucional do direito à saúde, tal como outros direitos sociais contemplados na Carta Federal, e a existência de leis especificas que tratam da questão saúde não têm significado a garantia de sua efetividade, o que nos instigou a pesquisar o tema ${ }^{(8)}$.

(6) Não há dúvida de que para os efeitos do disposto no art. $60, \S 4^{2}$, IV da Constituição, o direito à saúde é uma cláusula pétrea, na medida em que se tutela a vida, a integridade física e psiquica da pessoa humana. Ademais, o Superior Tribunal Federal decidiu na ADIn n. 939 que os direitos e garantias não se esgotam no elenco do art. $5^{2}$ da CF/88, podendo ser identificados em outros dispositivos da Carta Federal. Ora, o direito à saúde, além de direito fundamental, é condicionante da dignidade humana, que é fundamento da República Federativa do Brasil (art. 19. III), justificando plenamente o seu enquadramento entre as cláusulas pétreas.

(7) MAUÉS, Antonio G. Moreira; SIMÓES, Sandro Alex. Op. cit., p. 477-478.

(8) Muitas são as normas constitucionais que tratam diretamente da saúde, o que pode demonstrar, a principio, preocupação do poder constituinte em conferir plena efetividade às ações, politicas e programas nessa área. Os arts. $7^{\circ}, X X \| l$ (redução de riscos no trabalho, por meio de normas de saúde, higiene e segurança), a EC n. 29/2000 (alinea e acrescentada ao inciso VII do art. 34, possibilitando a intervenção da União nos Estados e no Distrito Federal), a EC n. 29/ 2000 (alteração do inciso III do art. 35 que possibilita a intervenção dos Estados nos Municipios) e 0 art. 208, VII (inclui a assistência à saúde entre os programas suplementares à educação no ensino fundamental) são alguns exemplos dessas normas. Do ponto de vista infraconstitucional, o direito à saúde está contemplado na Lei Orgânica de Saúde - LOS, cujo conteúdo está disposto nas Leis ns. $8.080 / 90$ e $8.142 / 90$. Esta disciplina as questões financeiras e a participação da sociedade nas açōes de saúde; aquela, por sua vez, cuida da regulamentação politico-administrativa do SUS. 
Pretende-se com o presente trabalho estudar o direito à saúde como direito social, levando em consideração a história e a evolução dos direitos humanos. Neste sentido, considerou-se importante traçar as características do direito sanitário enquanto direito social consubstanciado de forma programática e progressiva nas normas internacionais de direitos humanos e sujeito à prestação positiva do Estado e compará-lo com os direitos de liberdade. Em seguida enveredou-se no campo de sua positivação constitucional para discutir então as dificuldades quanto à sua eficácia e efetividade.

Os limites da concretização judicial do direito sanitário são parte importante deste estudo, em especial os relativos à reserva do possivel que colocam em destaque as politicas públicas como meio de efetivação do direito humano à saúde, dai por que foram abordados em capítulo específico.

\section{O DIREITO SOCIAL À SAÚDE NA HISTÓRIA DOS DIREITOS HUMANOS}

O direito sanitário é um direito humano social(9) que tem origem no constitucionalismo contemporâneo, dai por que julgamos importante pinçar fragmentos da história constitucional relacionada com os direitos humanos para melhor compreender a sua importância.

Os direitos fundamentais surgiram na França de 1770, durante o movimento revolucionário que culminou com a Declaração de Direitos do Homem e do Cidadão de 1789. Como afirma Lima Júnior:(10)

"Nessa perspectiva, é natural que o liberalismo tenha dado importância fundamental a determinados direitos humanos, tidos como civis e politicos, e que se caracterizam exatamente por estabelecerem garantias do cidadão comum contra excessos do Estado concentrador de poderes e repressor do cidadão. Essa característica do liberalismo, explica, portanto, o reconhecimento anterior dado aos direitos humanos civis e políticos, em detrimento dos direitos humanos econômicos, sociais e culturais."

(9) Cf. José Afonso da Silva, "os direitos sociais, como dimensão dos direitos fundamentais do homem, são prestações positivas estatais, enunciadas em normas constitucionais, que possibilitam melhores condiçōes de vida aos mais fracos, direitos que tendem a realizar a igualização de situações sociais desiguais. São, portanto, direitos que se conexionam com o direito de igualdade. Valem como pressupostos do gozo dos direitos individuais na medida em que criam condições materiais mais propicias ao auferimento da igualdade real, o que, por sua vez, proporciona condição mais compativel com o exercicio efetivo da liberdade". Curso de direito constitucional positivo, 9. ed. rev. 3. tir., São Paulo: Malheiros Ed., 1993. p. 258.

(10) LIMA JÚNIOR, Jayme Benvenuto. Os direitos humanos económicos, sociais e culturais, Rio de Janeiro: Renovar, 2001. p. 19. 
Ao lado dos direitos fundamentais de liberdade que permearam a Declaração Americana dos Direitos do Homem de 1776 e a Declaração francesa de 1789 , surgiram os direitos fundamentais sociais, cujo conteúdo nuclear típico consiste em prestações estatais que se sujeitam à conformação politico-legislativa, cuja gênese se deu nas Constituições francesas de 1791 e 1793.

A plena afirmação dos direitos humanos sociais e econômicos só ocorreu no primeiro quartel do século XX, com a Constituição mexicana de 1917 e a Constituição de Weimar de 1919. A Declaração do Povo Trabalhador e Explorado, de janeiro de 1918, verdadeiro contraponto proletário à Declaração burguesa de 1789 , consagrou a ética social, marcada pelo valor da igualdade material, como forma de combater a opressão e a exploração econômica, representando um contraponto à visão individualista do ser humano abstrato que caracterizou a Declaração francesa de 1789.

O sentido universal que permeou as Declarações de direito, passou a ser reconhecida além do âmbito estatal em documentos de feição multinacional propostos por organizações internacionais no segundo quartel do século $X X$, iniciando o processo de internacionalização e universalização dos direitos humanos. Mas, nos meados do século passado, como conseqüência da Segunda Guerra Mundial é que se dá a consolidação do Direito Internacional dos Direitos Humanos.

A preocupação com os direitos humanos delineada na Carta das Nações Unidas de 1945 acabou se concretizando mediante a Declaração Universal dos Direitos do Homem elaborada pela ONU, aprovada por sua Assembléia Geral em 10.12.1948. Tal Declaração contempla duas categorias de direitos humanos, desde logo, indivisiveis, quais sejam: os direitos civis e políticos (arts. $3^{\circ}$ a 21 ) e os direitos sociais, econômicos e culturais (arts. 22 a 28) combinando o "discurso liberal e o discurso social da cidadania, conjugando o valor da liberdade ao valor da igualdade", na feliz sintese de Piovesan(11).

Em 1966, após longa gestação, dois tratados internacionais passaram a incorporar os direitos humanos constantes da Declaração Universal de 1948: o Pacto Internacional dos Direitos Civis e Políticos e o Pacto Internacional dos Direitos Econômicos, Sociais e Culturais que são diplomas jurídicos vinculantes e obrigatórios ${ }^{(12)}$.

(11) PIOVESAN, Flávia. Direitos humanos e direito constitucional internacional, 4. ed. rev. e atual. São Paulo: Max Limonad, 2000. p. 143.

(12) Ambos os Pactos entraram em vigor internacional apenas em 1976. No Direito interno. como dito anteriormente, o Direito Sanitário foi reconhecido na Carta Federal de 1988 como garantia constitucional de competência do Poder Público, abrindo caminho para a elaboração de leis protetoras da saúde do cidadão brasileiro. No entanto, esses Pactos internacionais foram ratificados pelo Brasil somente em 24.1.1992. 
Os importantes avanços enunciados pela Declaração Universal dos Direitos Humanos foram reiterados em 1993 na II Conferência Mundial de Direitos Humanos, havida em Viena. A Declaração e o Programa de Ação de Viena declaram solenemente, no $\S 5^{\circ}$, que:

"Todos os direitos humanos são universais, indivisiveis, interdependentes e inter-relacionados. A comunidade internacional deve tratar os direitos humanos de forma global, justa e eqüitativa, em pé de igualdade e com a mesma ênfase. (...), é dever dos Estados promover e proteger todos os direitos humanos e liberdades fundamentais, sejam quais forem seus sistemas politicos, econômicos e culturais."

O direito sanitário, tema central deste artigo, encontra-se consubstanciado de forma programática e progressiva, a teor do que dispõe o $\S 1^{\circ}$ do art. $2^{\circ}$ do Pacto Internacional dos Direitos Econômicos, Sociais e Culturais de 1966. Nesse sentido, sua efetivação depende de órgãos que o convalide, como se depreende da leitura do $\S 2^{\circ}$ do art. 12 do mesmo Pacto:

"As medidas que os Estados-Partes no presente Pacto deverão adotar, com o fim de assegurar o pleno exercicio deste direito, incluirão as medidas que se façam necessárias para assegurar:

a) a diminuição da mortinatalidade da mortalidade infantil, bem como o desenvolvimento são das crianças;

b) a melhoria de todos os aspectos de higiene do trabalho e do meio ambiente;

c) a prevenção e o tratamento das doenças epidêmicas, endêmicas, profissionais e outras, bem como a luta contra essas doenças;

d) a criação de condições que assegurem a todos assistência médica e serviços médicos em caso de enfermidade."

Neste contexto, há uma corrente que considera os direitos humanos econômicos e sociais exigiveis apenas mediante a definição de politicas públicas correspondentes e não de mecanismos juridicos de exigibilidade, o que os distinguiria dos direitos civis e politicos. Tal critério de distinção carece de sustentação, na medida em que os direitos humanos da liberdade também precisam de politicas públicas correspondentes para sua validação, aliadas a mecanismos juridicos de exigibilidade. Para tanto, basta lembrar, como Lima Júnior ${ }^{(13)}$, da existência de planos, diretrizes e órgãos governamentais que inserem os direitos civis e politicos na seara das politicas públicas, sem as quais os mecanismos jurídicos têm suas possibilidades de existência bastante reduzidas. Em outras palavras, quer

(13) LIMA JÚNIOR, Jayme Benvenuto. Op. cit., p. 80-81. 
sejam civil, político, econômico, social ou cultural, os direitos humanos exigem a adoção de politicas públicas destinadas a tornar realidade as definições legais desses direitos.

Outro ponto distintivo seria a capacidade de aplicação imediata dos direitos humanos. Nesse sentido, apenas os direitos humanos civis e politicos teriam possibilidade de validação imediata, porquanto são exigiveis pelos individuos contra o Estado. Já os direitos humanos sociais que incluem a saúde, por exemplo, seriam exigiveis mediante ações de politica pública, uma vez que a sua validação ocorreria de forma progressiva, num processo de incorporação que dependeria fortemente do desenvolvimento econômico dos Estados. Para rebater tal assertiva com a qual não concordamos, lembra-se que os direitos trabalhistas são exigiveis imediatamente, isso porque além da existência de uma politica governamental contam com uma legislação correspondente, dotada de instrumentos especificos e adequada à sua justiciabilidade ${ }^{(14)}$.

A Constituição Federal de 1988 não se quedou silente à positivação internacional dos direitos humanos, indo além, ao incorporar ao direito interno as normas de direitos e garantias decorrentes de tratados internacionais em que o Brasil seja parte (art. $5^{\circ}, \S 2^{\circ}$ ), reiterando conseqüentemente não só os direitos constitucionalmente assegurados, mas também os novos direitos civis, políticos, econômicos, sociais e culturais.

Além da brasileira, a maioria das constituições européias incorporou no seu bojo as disposições ou os preceitos dos direitos humanos sociais. Ainda que as necessidades do homem sejam diferentes em cada sociedade, momento ou mesmo circunstância, essas constituições carregam em si diversas expectativas sociais que demandam a diligência não só do legislador, mas principalmente da Administração Pública na concretização e na efetivação desses direitos. Demais disso, impende observar que muitas são as constituições européias e sul-americanas que contemplam disposições expressas do direito à saúde como direito fundamental, entre elas, as Constituições da Espanha, França, Grécia, Holanda, Itália, Argentina, Paraguai, Peru e Uruguai.

Percebe-se claramente não obstante a brevidade deste escorço histórico, a dicotomia da linguagem dos direitos humanos. De um lado há o direito à liberdade, característico dos direitos civis e políticos, no outro, o direito à igualdade que cunha os direitos econômicos, sociais e culturais. No que pertine à natureza individual ou coletiva dos direitos humanos, nota-se que os direitos humanos civis e politicos têm uma natureza claramente individual, na medida em que são garantidos aos cidadãos contra o poder do Estado, seguindo o plano da teoria liberal que pretende limitar ao máximo a interferência estatal sobre a vida das pessoas. Por outro lado, os direitos humanos econômicos, sociais e culturais têm feição coletiva, na medida em que exigem uma ação efetiva do Estado para a sua validação e acessibilidade a todos os cidadãos.

(14) LIMA JUNIOR, Jayme Benvenuto. Op. cit., p. 81. 


\section{A EFICÁCIA E A EFETIVIDADE DO DIREITO SANITÁRIO}

O direito sanitário, conforme já exposto, é um direito social, pertencendo à segunda geração dos direitos humanos que impregnaram o chamado Estado social de Direito em evolução ao Estado liberal-burguês de Direito(15).

O direito sanitário é considerado simultaneamente um direito de defesa, de natureza negativa, na perspectiva de se impedir uma ação indevida do Estado e de terceiros que possa lesar a saúde do titular e, um direito à prestação, de natureza positiva, que se impõe ao Estado na consecução de politicas públicas que visem à efetivação desse direito a todos os cidadãos, que incluem, entre outras prestações materiais, o atendimento médico, ambulatorial e hospitalar, a realização de exames e o fornecimento de medicamentos diversos; enfim, toda ação e serviço que promova, proteja e recupere a saúde (CF, art. 196).

O art. $5^{\circ}, \S 1^{\circ}$ da nossa Constituição prevê que as normas definidoras dos direitos e garantias fundamentais têm aplicação imediata, donde se pode concluir que essas normas não mais dependem de uma concretização pelo legislador infraconstitucional para que possam gerar a plenitude de seus efeitos ${ }^{(16)}$.

Silva ${ }^{(17)}$ considera que a norma contida no art. $5^{\circ}, \S 1^{\circ}$ da nossa Constituição é uma norma-sintese do plano constitucional de que os direitos humanos, assim entendidos os direitos fundamentais: individuais, coletivos, sociais, de nacionalidade e politicos, só cumprem sua finalidade se as normas que os contemplam tiverem efetividade. Sarlet ${ }^{(18)}$, por sua vez, entende que essa disposição, "aplicável a todos os direitos fundamentais (incluindo os direitos sociais)", é uma norma-principio "que se constitui em uma espécie de mandado de otimização, impondo aos órgãos estatais a tarefa de reconhecerem e imprimirem às normas de direitos e garantias fundamentais a maior eficácia e efetividade possivel".

(15) Para um estudo mais detalhado sobre as dimensões/gerações dos direitos humanos, vejase, entre outros: SARLET, Ingo Wolfgang. A eficácia dos direitos fundamentais. Porto Alegre: Livraria do Advogado, 2000. p. 48-60; BONAVIDES, Paulo. Curso de direito constitucional. 10. ed. rev., atual., e ampl. São Paulo: Malheiros Ed., 2000. p. 516-527; e LAFER, Celso. A reconstrução dos direitos humanos: um diálogo com o pensamento de Hannah Arendt. São Paulo: Companhia das Letras, 1998. p. 125-134.

(16) Sobre o problema da interpretação hermenêutica dos direitos sociais em razão da expressão "direitos e garantias individuais" do art. $60, \S 4^{2}$, IV, da CF/88, ver, por todos, Paulo Bonavides, op. cit., p. 588-599. Não assiste razão aos que defendem a interpretação meramente gramatical dessa norma e do art. $5^{9}, \S 2^{\circ}$ de que tais disposições nảo se aplicam aos direitos sociais e conseqüentemente ao direito humano à saúde.

(17) SILVA, José Afonso da. Aplicabilidade e eficácia das normas constitucionais, 2. ed. São Paulo: Ed. Revista dos Tribunais, 1985. p. 444.

(18) SARLET, Ingo Wolfgang. Algumas consideraçōes em torno do conteúdo, cit., p. 9. 
Com efeito, a norma insculpida no art. $5^{\circ}, \S 1^{9}$, da CF/88 possibilita ao operador do direito, que enfrenta uma situação em que esteja em jogo um dado direito fundamental, criar meios de conferir efetividade a esse direito, independentemente da existência de norma infraconstitucional integradora e mesmo contra norma infraconstitucional que esteja dificultando a concretização do direito. E mais. Com exegese no art. $5^{\circ}, \S 2^{\circ}$, da CF de 1988 é possivel extrair novos direitos fundamentais mesmo fora do rol nele elencado.

Desse modo, quando alguém diz que os direitos sociais não possuem ou não podem possuir aplicação direta e imediata por não estarem elencados no art. $5^{\circ}$ da Carta Federal de 1988 é um argumento que absolutamente não pode prevalecer, isso porque não leva em conta que a aplicação direta e imediata se funda no principio da máxima efetividade inerente a qualquer norma constitucional, sobretudo as definidoras de direito(19).

Se Constituição diz que a saúde é um direito de todos e indica políticas, mecanismos e a forma de recursos para satisfação desse direito, aí está caracterizada a sua primeira condição de eficácia jurídica, tornando-o justiciável.

As teorias desenvolvidas no sentido de superar a concepção de eficácia minima das normas definidoras de direitos sociais são bastante semelhantes na medida em que dão destaque à força juridica potencializada das normas definidoras de direitos fundamentais e as consideram de hierarquia superior, distinguindo-se quanto à possibilidade de interferência judicial. Tais teorias defendem de modo geral, que, dentro da reserva do possivel, o Poder Público deve implementar os direitos sociais. Não o fazendo, restando caracterizada a inércia governamental na realização de uma prestação social constitucional, caberá ao Judiciário proporcionar as medidas necessárias ao cumprimento do direito social, por exemplo, a saúde, visando à máxima efetividade da Constituição(20).

Todas as normas já citadas e outras relativas à saúde possuem eficácia juridica, em maior ou menor grau, razão pela qual devem ser utilizadas para fundamentar pedidos ou mesmo decisões em que se discute a concretização do direito à saúde. Se amplas são as possibilidades de concretização desse direito, diante do principio da máxima efetividade das normas constitucionais, há limites, pois nenhum direito pode ser considerado absoluto.

(19) Nas palavras de Celso António Bandeira de Mello: "Todas as normas constitucionais concernentes à Justiça Social - inclusive as programáticas - geram imediatamente direitos para os cidadãos, inobstante tenham teores eficaciais distintos. Tais direitos são verdadeiros 'direitos subjetivos', na acepção mais comum da palavra". Eficácia das normas constitucionais sobre justiça social. Revista de Direito Público, São Paulo, v. 57/58. p. 255, 1991.

(20) A esse respeito, v. na doutrina: SARLET, Ingo Wolfgang. A eficácia dos direitos fundamentais. Porto Alegre: Livraria do Advogado, 2000. p. 254-321; BONAVIDES, Paulo. Curso de direito constitucional, 10. ed. rev., atual., e ampl. São Paulo: Malheiros, 2000. p. 532-588; BARROSO, Luis Roberto. O direito constitucional e a efetividade de suas normas, 5. ed., Rio de Janeiro: Renovar, 2001. p. 117 e ss. 


\section{LIMITES DA CONCRETIZAÇÃO JUDICIAL DO DIREITO SANITÁRIO}

A afirmação de que o direito humano à saúde pode ser limitado através de uma norma infraconstitucional pode soar inicialmente estranho, até porque se procurou neste estudo demonstrar que a saúde é um direito fundamental constitucional e como tal possui um grau máximo de juridicidade e normatividade. Dois argumentos podem ser inicialmente invocados para justificar a limitação ao direito à saúde: sua natureza é muito abrangente, e além disso, mesmo valores atrelados a principios absolutos, como a vida, podem ser objeto de limitações normativas (por exemplo, as excludentes de antijuridicidade no crime de homicidio: estrito cumprimento do dever legal, legitima defesa ou estado de necessidade).

Para entender a validade juridica das limitações aos direitos fundamentais é necessário compreender que esses direitos têm o caráter normativo de principios e não de regras. Segundo Alexy (21), "principios são normas que ordenam que algo seja realizado em uma medida tão ampla quanto possivel relativamente a possibilidades fáticas ou juridicas. Principios são, portanto, mandamentos de otimização". As regras, por sua vez, consoante a lição de Canotilho(22), "são normas que prescrevem imperativamente uma exigência (impõem, permitem ou proibem) que é ou não é cumprida (nos termos de Dworkin: applicable in all-or-nothing fashion)".

Os direitos fundamentais consagrados na Carta Federal de 1988 têm uma estrutura principiológica, donde se conclui que não são absolutos, ainda mais considerando que interesses até antagônicos por ela foram acolhidos.

Com relação ao direito sanitário, embora a principio haja um interesse geral pela sua máxima efetivação, é possivel que em um dado momento a vida de uma pessoa possa depender do sacrifício da saúde ou da própria vida de outra pessoa, caracterizando, portanto, a colisão entre direitos fundamentais ${ }^{(23)}$.

A doutrina tem alvitrado que direito consubstanciado em status positivus tem uma conflituosidade própria. Qualquer prestação que tenha por suporte demandas orçamentárias poderá, em alguma situação, res-

(21) ALEXY, Robert. Colisão de direitos fundamentais e realizaçăo de direitos fundamentais no Estado de direito democrático. Revista de Direito Administrativo, Rio de Janeiro, v. 1, p. 74-75, 1999.

(22) CANOTILHO, José Joaquim Gomes. Direito constitucional e teoria da Constituiçăo, 6. ed., Coimbra: Almedina, 2003. p. 1147. Com a maestria que the é singular, o autor fornece os traços distintivos entre principios e regras nas p. 1146-1148 dessa obra.

(23) São exemplos de colisão entre direitos fundamentais em que o direito à saúde está em jogo: a interrupção da gravidez que esteja pondo em risco a saúde da gestante; pais que não autorizam a transfusão de sangue nos filhos por motivos religiosos. 
valar no dominio do campo do possivel, criando a inexeqüibilidade do atendimento a todos, simultaneamente, ou ainda, pode-se instalar as escolhas dramáticas, onde dois direitos são legítimos e legais, mas apenas um poderá ser atendido(24).

Surgem, então, as seguintes questões: $O$ atendimento de um direito implica necessariamente a negação do outro? Quais os direitos a prestar? Como escolher a quem prestar? De que forma fazer atuar o direito neste campo, promovendo as transformações sociais que dele espera a sociedade?

Feita essa breve digressão que absolutamente não esgota o tema, o próximo passo deste estudo é discutir os limites de concretização do direito sanitário, que são basicamente três: a reserva do possivel, o princípio da proporcionalidade e a reserva de consistência.

\subsection{O limite da reserva do possivel}

A reserva do possivel parece ser o limite mais visivel à concreção do direito social à saúde, o que é compreensivel na medida em que é uma prestação do Estado diretamente vinculada à destinação, à distribuição e à criação de bens materiais e, portanto, tem caráter econômico.

É exatamente esta característica que assume importância no plano da eficácia e efetivação do direito sanitário, significando para Sarlet ${ }^{(25)}$, "que a efetiva realização das prestações reclamadas não é possivel sem que se despenda algum recurso, dependendo em última análise, da conjuntura econômica". Observa o autor, que a problemática da efetiva disponibilidade do objeto da prestação está diretamente vinculada a esta caracteristica econômica, ou seja, a questão é saber se o destinatário da norma está em condições de cumprir o que a norma lhe impõe, já que depende da existência de recursos para executar sua obrigação.

O direito à saúde, de modo semelhante ao que ocorre com outros direitos sociais que exigem prestações positivas, tais como a educação, a moradia e a assistência social, entre outros, não foi reconhecido, na dicção de Sarlet(26), como um direito subjetivo individual exatamente porque depende de intermediação legislativa, não se lhe aplicando, portanto, a natureza de norma eficácia plena, mas sim de eficácia limitada. Nessa concepção, a saúde é um direito que implica alocação de recursos materiais e humanos os quais dependem da disponibilidade de recursos que são finitos, justificando sua submissão a uma reserva do possivel.

(24) Sobre o tema, v. obra de Gustavo Amaral que examina a questão da legitimidade da pretensão do cidadão em razão da provisão de recursos públicos. Nela, a questão saúde é bastante enfatizada, aplicando-se, porém, para a generalidade dos direitos humanos sociais. Direito, escassez \& escolha: em busca de critérios juridicos para lidar com a escassez de recursos e as decisōes trágicas. Rio de Janeiro: Renovar, 2001. p. 133-185.

(25) SARLET, Ingo Wolfgang. A eficácia dos direitos fundamentais, cit., p. 259-260.

(26) Id. Ibid., p. 297-298. 
Tem-se defendido que ninguém tem direito subjetivo em face do Estado para a obter a realização de prestação concernente ao direito social. Mas, na lição de Canotilho:(27)

"Os direitos sociais são compreendidos como autênticos direitos subjectivos inerentes ao espaço existencial do cidadão, independentemente da sua justicialidade e exeqüibilidade imediatas. Assim, (...), o direito à saúde (art. 64), (...), são direitos com a mesma dignidade subjectiva dos direitos, liberdades e garantias. Nem o Estado nem terceiros podem agredir posições juridicas reentrantes no âmbito de proteç̧ão desses direitos (ex.: saúde)." Tomando como exemplo o direito à saúde, explica o autor lusitano ser "um direito social, independentemente das imposições constitucionais destinadas a assegurar a sua eficácia (ex.: a criação de um serviço nacional de saúde (...) e das prestações fornecidas pelo Estado para assegurar o mesmo direito (...)". Os grifos são originais.

Debruçando mais sobre o tema, Sarlet $t^{(28)}$ discorre sobre os padrões de qualidade que o Estado estaria obrigado a prestar, o que chama de clássico dilema do Estado social em relação às suas funções precípuas, isto é, se os serviços de saúde devem seguir padrões minimos suficientes para assegurar a efetividade das prestações ou então de padrão ótimo. No entanto, diante de prestações de cunho emergencial, cujo indeferimento acarretaria o comprometimento ou mesmo o sacrifício irreversivel de bens essenciais da própria vida, integridade física e dignidade humana, o autor reconhece, ao revés, um direito subjetivo individual à prestação reclamada em juizo, desde marcada pelo principio da razoabilidade.

Neste passo, pondera-se que o Estado, o legislador e outros destinatários da norma estarão sempre vinculados a proteger o direito à vida - o bem maior do ser humano - , de sorte que na seara das prestações existenciais minimas, cabe-lhes escolher o meio ou conjunto de meios hábeis a tornar efetivo o direito à vida.

Aqui é que ganham importância as políticas públicas, que são um complexo de decisões e normas de natureza variada, e surgem algumas questões que ainda não foram adequadamente respondidas. Para promover a saúde o que deve fazer o Estado? Quais os limites constitucionais, quais as direções impostas pela Constituição? Uma política de saúde dependerá basicamente de gastos públicos, de curto, médio e longo prazo e legislação que discipline as atividades pertinentes à saúde. A legislação deve cuidar da organização do serviço público ou da promoção indireta do serviço de saúde por empresas particulares. Aduz Lopes ${ }^{(29)}$ que a última

(27) CANOTILHO, José Joaquim Gomes. Op. cit., p. 474-475.

(28) SARLET, Ingo Wolfgang. A eficácia dos direitos fundamentais, cit., p. 298

(29) LOPES, José Reinaldo de Lima. Direito subjetivo e direitos sociais: o dilema do Judiciário no Estado social de direito. In: FARIA, José Eduardo (Coord.). Direitos humanos, direitos sociais e justiça. 1. ed. 2. tir. Săo Paulo: Malheiros Ed., 1998. p. 131-132. 
opção implica a promoção de legislação e o exercicio efetivo do poder de polícia através de atividades de fiscalização, autorização e coordenação, com estímulo indispensável à coordenação das atividades estatais, privadas e entre si.

As tarefas fundamentais do Estado previstas constitucionalmente representam as metas e ações que acabam convergindo para a Constituição econômica, já que a efetivação dos direitos far-se-á mediante a transformação e modernização das estruturas econômicas e sociais do Estado. Por essa razão, as constituições têm suporte financeiro no seu sistema tributário, que por sua vez deve estar apto a levar o Estado a cumprir todas as suas funções, inclusive aquelas que o legislador infraconstitucional decidir implementar pela regulamentação de um direito social constitucionalmente delineado ${ }^{(30)}$.

Para compreender as politicas públicas é essencial conhecer o regime de finanças públicas, e para compreender estas é necessário inseri-las nos princípios constitucionais que estão além dos limites ao poder de tributar. $\mathrm{Na}$ precisa lição de Lopes $^{(31)}$, as políticas públicas "precisam ser inseridas no direito que o Estado recebeu de planejar não apenas suas contas mas de planejar o desenvolvimento nacional, que inclui e exige a efetivação de exercícios dos direitos sociais pelos cidadãos brasileiros. Assim, o Estado não só deve planejar seu orçamento anual mas também suas despesas de capital e programas de duração continuada (art. 165, § $1^{\circ}$ )".

Conclui-se, com base nessa conformação econômico-financeira do Estado, que tudo aquilo que o impeça de implementar os direitos sociais importa em limitação econômica à consecução desses direitos. Assim, pode-se considerar, de inicio, que a ausência de dotação orçamentária especifica ao atendimento de um determinado direito social representa seguramente um limite econômico a esse direito. Mas, não é só isso. 0 Estado tem uma série de direitos prestacionais a cumprir e para dispor os serviços correspondentes encontra outras limitações econômicas que dizem respeito, por exemplo, à proibição de confisco, às garantias dos contribuintes, ao pagamento das remunerações de seus servidores e dos contratantes pelas aquisições por efetuadas pelo próprio Estado.

Há, como se percebe, um verdadeiro confronto de direitos para que o Estado possa efetivar um direito humano social, podendo-se inferir que o próprio sistema estatal representa um limite econômico à efetivação dos direitos sociais.

(30) V. na CF/88 as regras de tributação e orçamento do Titulo VI (arts. 145 a 169), em especial as normas de finanças públicas do Capitulo II (arts. 163 a 169), as quais traçam os contornos das necessidades financeiras, com o objetivo de aplicação no desenvolvimento econômico e social. $\dot{E}$ com base neste suporte financeiro que é possivel prever verbas suplementares destinadas especificamente ao atendimento dos direitos sociais, entre eles, o direito humano à saúde.

(31) LOPES, José Reinaldo de Lima. Op. cit., p. 132-133. 
A fiscalização deficiente de gastos públicos e a ineficiência na prestação do serviço público também representam um limite econômico ao cumprimento dos direitos sociais, de sorte que o desempenho da função prestacional do Estado depende de uma boa fiscalização nos gastos públicos e da melhoria na eficiência dos serviços estatais ${ }^{(32)}$.

Em razão da reserva do possivel, o juiz não pode ficar indiferente quanto à viabilidade material de sua decisão, em particular em matéria de saúde. É preciso lembrar que os recursos são finitos e verificar até que ponto sua decisão será passivel de atendimento sem pôr em risco o equilíbrio financeiro do Sistema Único de Saúde. Entretanto, o juiz deve analisar detidamente toda e qualquer alegação de negativa de efetivação de um direito à saúde com base no argumento da reserva do possivel. Não basta o destinário da norma simplesmente alegar que não há possibilidades financeiras de cumprir a ordem judicial, é preciso demonstrá-la. Portanto, o argumento da reserva do possivel somente deve ser acolhido se o Poder Público demonstrar suficientemente que a decisão causará mais danos do que vantagens à efetivação do direito humano à saúde.

A expressão reserva do possivel do que se tratou até aqui tem natureza fática - reserva fática do possivel - referindo-se à possibilidade material do destinário da norma em cumprir a prestação social. Além disso, a doutrina tem apontado outra faceta diversa que compreende o poder de disposição do destinário da norma, já que o Estado (ou outro destinatário) deve ter a capacidade jurídica de dispor a prestação social - reserva juridica do possivel, sem o que de nada adiantaria contar com os recursos necessários.

\subsection{O principio da proporcionalidade}

Os direitos fundamentais, conforme já assinalado, são dotados de elevada carga axiológica porque são normas-principios, razão pela qual vivem em um estado de tensão permanente, limitando-se reciprocamente.

Diferentemente das regras que conhecem somente a alternativa validade ou não-validade, os principios devem ser ponderados e assim, como preleciona Alexy(33), "são dependentes de uma 'reserva do possivel' no sentido do que o particular pode exigir razoavelmente da sociedade". Em

(32) A Lei de Responsabilidade Fiscal (Lei Complementar n. 101, de 4.5.2001) pode descortinar um novo panorama no controle e fiscalização do orçamento público. Estabelece 0 art. $1^{2}$ um conjunto de regras para condicionar a ação estatal de modo a prevenir riscos e corrigir desvios capazes de afetar o equilibrio das contas públicas. Através de uma série de mecanismos que abrangem proibições aos agentes públicos e estimulo às formas de controle institucional e social, esta lei pretende atingir situação de equilibrio, buscando evitar que a ação estatal conduza à realização de despesas em montante superior à receita e à capacidade de endividamento do Estado.

(33) ALEXY, Robert. Op. cit., p. 79. 
apertada sintese: ora um principio prevalecerá em detrimento de outro, ora ocorrerá o contrário; porém, nenhum deles será afastado do ordenamento, até porque haverá o balanceamento de valores e interesses, segundo o seu peso e a ponderação de outros principios eventualmente conflitantes, sendo a harmonização entre eles perfeitamente possivel.

Havendo uma colisão entre direitos fundamentais, é possivel limitar o raio de abrangência de um desses direitos com base no principio da proporcionalidade, visando dar maior efetividade ao outro direito fundamental em jogo.

A doutrina tem apontado três critérios do principio da proporcionalidade: a) a adequação( ${ }^{(34)}$; b) a necessidade ou vedação de excesso(35); e c) a proporcionalidade em sentido estrito. Esses critérios correspondem, respectivamente, às seguintes perguntas que devem ser feitas para se analisar a validade de medida limitadora: a) o meio escolhido foi adequado e pertinente para atingir o resultado almejado?; b) o meio escolhido foi o necessário e menos oneroso entre as opções existentes?; c) o beneficio alcançado com a adoção da medida buscou preservar direitos fundamentais axiologicamente mais importantes do que os direitos que a medida limitou? Assim, se todas as respostas a estas perguntas forem afirmativas, será legitima a limitação ao direito fundamental.

Veja-se o seguinte exemplo que pode ilustrar a utilização do principio da proporcionalidade. Um paciente com problemas visuais necessita ser submetido a uma cirurgia de transplante de córneas. Como a disponibilidade de córneas é bastante limitada, ele deve aguardar sua vez em uma lista de espera que deve ser observada para evitar favorecimentos. Uma medida que determinasse ao Poder Público que procedesse a imediata cirurgia desse paciente, sem observância da ordem estabelecida, seria, certamente, desproporcional, pois o beneficio alcançado com tal medida estaria sacrificando o direito de inúmeros outros pacientes, numa clara ofensa à proporcionalidade em sentido estrito e da igualdade, que se acha intimamente ligado à noção de proporcionalidade.

Inadequada seria, também, uma ordem judicial que obrigasse o Poder Público a fornecer um medicamento ineficaz a um paciente ou determinasse que o SUS arcasse com uma cirurgia imprópria ao tratamento de uma dada doença. O principio da proporcionalidade impõe que a medida deve ser adequada e pertinente a atingir os fins almejados de saúde.

(34) Não se pode considerar adequada, por exemplo, uma medida que proíbe o consumo de bebidas alcoólicas no carnaval com a finalidade de diminuir os casos de disseminação do virus da AIDS, uma vez que não há relação de causa e efeito entre álcool e disseminação do virus da AIDS, ou seja, não existe adequação entre o meio utilizado (proibição de venda de bebida alcoólica) e o fim visado (diminuição da disseminação do HIV).

(35) Se um determinado tratamento médico pode ser feito no Brasil, a baixo custo, violaria o principio da proporcionalidade (vedação de excesso) uma ordem judicial que determinasse que esse tratamento fosse feito no exterior, acarretando uma maior onerosidade para o Poder Público. 
Para concluir, adverte-se que o principio da proporcionalidade não é critério útil somente para verificar a validade material de atos do Poder Legislativo ou do Poder Executivo que limitem direitos humanos à saúde, mas também para, reflexivamente, balizar a própria legitimidade da decisão judicial, servindo, nesse aspecto, como verdadeiro limite da atividade jurisdicional. O juiz, ao concretizar um direito humano à saúde, também deve estar consciente que sua ordem deve ser adequada, necessária, não excessiva e proporcional em sentido estrito.

\subsection{O limite da reserva de consistência}

Ensina Moro(36) que: "não podem ser desenvolvidas e efetivadas normas constitucionais sem que o Judiciário reúna argumentos e elementos suficientes para demonstrar o acerto do resultado que pretende alcançar".

De acordo com o mesmo autor, "o limite da reserva de consistência poderá impedir o juiz de desenvolver e efetivar normas constitucionais que demandem a elaboração de politicas públicas de certa complexidade"(37). Assim, não sendo atingida carga de argumentação suficiente para demonstrar o acerto da escolha politica, recomenda-se o reconhecimento de que, por não ter sido demonstrada a presença de vício de inconstitucionalidade do ato controlado, a demanda deverá ser julgada a favor do Poder Público, prestigiando, com isso, as soluções adotadas pelos demais poderes constituidos e, conseqüentemente, a harmonia entre os poderes.

A reserva de consistência implica a necessidade de explicitação de todos os motivos que levaram o juiz a tomar sua decisão, ampliando-se, ao máximo, a possibilidade de participação dos diversos segmentos sociais interessados nos resultados do julgamento, a fim de legitimar e democratizar cada vez mais o processo de concretização constitucional. Dessa forma, as razões de decidir deixam de ser meramente jurídicas, cabendo ao juiz, antes de decidir, buscar dados empiricos em outras ciências, requisitar informações especialistas em saúde de entidades públicas e privadas, no intuito de julgar o feito do modo mais correto possivel, aproximando-se ao máximo da verdade material ${ }^{(38)}$.

(36) MORO, Sérgio Fernando. Desenvolvimento e efetivaçăo judicial das normas constitucionais. São Paulo: Max Limonad, 2001, p. 90.

(37) Id. Ibid., p. 179.

(38) Confira-se, por exemplo, o seguinte julgado colacionado por Sérgio Fernando Moro. A Suprema Corte Norte-Americana, no caso Roe v. Wade, de 1973, ao analisar leis estaduais que criminalizavam indiscriminadamente a prática do aborto serviu-se de trabalhos e estatísticas médicas em sua argumentação, concluindo, com base nesses dados, que somente em certas circunstâncias seria licita a proibição da prática do aborto, salvo quando este fosse necessário para preservar a vida e a saúde da gestante, op. cit., p. 95. 
Quanto maior a participação de setores da sociedade no processo, maior será a possibilidade de acerto, razão pela qual devem ser incentivadas ações que possibilitem que entidades ligadas à saúde participem do processo de tomada de decisão(39).

Não há dúvida de que o limite imposto pela reserva de consistência é de especial relevância em casos envolvendo a saúde, já que uma decisão precipitada, sem levar em conta todos os interesses em jogo, pode causar lesão ao SUS, na medida em que os recursos financeiros destinados ao setor são escassos e podem não ser suficientes para o cumprimento da ordem judicial, especialmente se for verificada a repercussão que teria a decisão se fosse estendida a casos análogos.

O principio da reserva de consistência amplia as possibilidades de atuação judicial, na medida em que permite um maior aprofundamento na matéria a ser decidida, constituindo, paradoxalmente, um fator limitador da atividade do juiz na medida em que impede que ele desenvolva e efetive politicas públicas de certa complexidade.

\section{CONCLUSÃO}

O direito sanitário é um direito humano social e direito público subjetivo, tendo posição de destaque na nossa Constituição Federal de 1988 que o consagrou pioneiramente como direito e dever da pessoa humana, abrindo caminho para que todos os cidadãos brasileiros possam usufruir saúde.

O direito sanitário foi elevado como um principio constitucional de justiça social. Assim a sua não-efetivação pelo Estado contraria frontalmente o fundamento da dignidade da pessoa humana que é um dos pilares do Estado Democrático de Direito.

Ao proclamar a saúde como um direito de todos e ao indicar políticas, mecanismos e a forma de recursos para satisfação desse direito, a Carta Federal de 1988 cristalizou a sua primeira condição de eficácia juridica, tornando-o justiciável.

A Constituição brasileira de 1988 permitiu um avanço extraordinário na teoria juridica dos direitos fundamentais, reconhecendo nesses direitos uma força juridica efetiva e potencializada ao enquadrá-los como norma hierárquica superior e dando abertura à extração de novos direitos fundamentais $\left(C F\right.$, art. $\left.5^{\circ}, \S 2^{\circ}\right)$. O reconhecimento da aplicação direta e imediata dos direitos fundamentais (CF, art. $\left.5^{\circ}, \S 1^{\circ}\right)$ permite aos operadores do direito criar meios de dar efetividade a esses direitos.

(39) Os Conselhos Regionais de Medicina, os Conselhos de Saúde, as Organizações NãoGovernamentais, os médicos e suas associações podem fornecer subsidios valiosos para o Juiz, permitindo uma maior democratização na atividade jurisdicional centrada no direito humano à saúde. 
Tanto os direitos humanos econômicos e sociais como os direitos civis e politicos necessitam de politicas públicas correspondentes e de mecanismos jurídicos de exigibilidade para a sua validação, carecendo de sustentação a distinção entre essas duas dimensões de direitos baseada nesses critérios. Além disso, ambos os direitos têm capacidade de aplicação imediata.

Muitas são as teorias desenvolvidas no sentido de superar a concepção de eficácia mínima das normas definidoras de direitos sociais, concluindo, de forma geral, pela exigibilidade judicial dentro da reserva do possivel, diferindo quanto à possibilidade de interferência judicial.

A saúde é uma prestação positiva do Estado diretamente vinculada à destinação, à distribuição e à criação de bens materiais. A concreção do direito sanitário implica alocação de recursos materiais e humanos os quais dependem da disponibilidade de recursos que são finitos, justificando sua submissão a uma reserva do possivel.

A promoção da saúde depende necessariamente de políticas públicas com lastro em gastos públicos, legislação especifica que contemple a organização dos serviços públicos de saúde em toda a sua extensão, a fiscalização, bem como a coordenação das atividades estatais, privadas e entre si.

\section{BIBLIOGRAFIA}

ALEXY, Robert. Colisão de direitos fundamentais esrealização de direitos fundamentais no Estado de Direito Democrático. Revista de Direito Administrativo, Rio de Janeiro, v. 217, 1999.

AMARAL, Gustavo. Direito, escassez \& escolha: em busca de critérios juridicos para lidar com a escassez de recursos e as decisões trágicas. Rio de Janeiro: Renovar, 2001.

BARROSO, Luis Roberto. O direito constitucional e a efetividade de suas normas. 5. ed., Rio de Janeiro: Renovar, 2001.

BONAVIDES, Paulo. Curso de direito constitucional, 10. ed. rev., atual., e ampl. São Paulo: Malheiros Ed., 2000.

CANOTILHO; José Joaquim Gomes. Direito constitucional e teoria da Constituição. 6. ed., Coimbra: Almedina, 2003.

DALLARI, Sueli Gandolfi. Direito sanitário. In: Curso de especialização em direito sanitário para membros do Ministério Público e da Magistratura Federal/Ministério da Saúde. Programa de Apoio ao Fortalecimento do Controle Social do SUS. Brasilia: Ministério da Saúde, 2002.

LAFER, Celso. A reconstrução dos direitos humanos: um diálogo com o pensamento de Hannah Arendt. São Paulo: Companhia das Letras, 1998. 
LIMA JÚNIOR, Jayme Benvenuto. Os direitos humanos econômicos, sociais e culturais. Rio de Janeiro: Renovar, 2001.

LOPES, José Reinaldo de Lima. Direito subjetivo e direitos sociais: o dilema do judiciário no estado social de direito. In: FARIA, José Eduardo (Coord.). Direitos humanos, direitos sociais e justiça. 1. ed. 2. tir. São Paulo: Malheiros Ed., 1998.

MAUÉS, Antonio G. Moreira e SIMŐES, Sandro Alex. Direito público sanitário constitucional. In: Curso de especialização em direito sanitário para membros do Ministério Público e da Magistratura Federal/Ministério da Saúde. Programa de Apoio ao Fortalecimento do Controle Social do SUS. Brasilia: Ministério da Saúde, 2002.

MELLO, Celso Antônio Bandeira de. Eficácia das normas constitucionais sobre justiça social. Revista de Direito Público, São Paulo, v. 57/58, 1991.

MORO, Sérgio Fernando. Desenvolvimento e efetivação judicial das normas constitucionais. São Paulo: Max Limonad, 2001.

PIOVESAN, Flávia. Direitos humanos e o direito constitucional internacional. 4. ed. rev. ampl. e atual., São Paulo: Max Limonad, 2000.

SARLET, Ingo Wolfgang. Algumas considerações em torno do conteúdo, eficácia e efetividade do direito à saúde na Constituição de 1988. Revista Diálogo Jurídico, Salvador, n. 10, 2002. Disponivel em <http://www.direito publico.com.br>. Acesso em 19.jul.2004.

A eficácia dos direitos fundamentais. Porto Alegre: Livraria do Advogado, 2000.

SILVA, José Afonso da. Curso de direito constitucional positivo. 9. ed. rev., 3. tir., São Paulo: Malheiros Ed., 1993.

Aplicabilidade e eficácia das normas constitucionais. 2. ed., São Paulo: Ed. Revista dos Tribunais, 1985. 